\title{
International Review of Public Policy
}

$1: 2 \mid 2019$

Regular Issue

\section{Where is the EU's Migrant Integration Policy Heading?}

A Neofunctionalist Take on Three Multiannual Financial Fraweworks

Pierre Georges Van Wolleghem

\section{(2) OpenEdition}

\section{Journals}

Electronic version

URL: http://journals.openedition.org/irpp/396

ISSN: 2706-6274

\section{Publisher}

International Public Policy Association

Printed version

Date of publication: 10 October 2019

Number of pages: 218-237

ISSN: 2679-3873

\section{Electronic reference}

Pierre Georges Van Wolleghem, « Where is the EU's Migrant Integration Policy Heading? », International Review of Public Policy [Online], 1:2 | 2019, Online since 10 December 2019, connection on 05 January 2020. URL : http://journals.openedition.org/irpp/396

International Review of Public Policy is licensed under a Creative Commons Attribution 4.0 International. 


\section{Where is the EU's Migrant Integration Policy Heading? A Neofunctionalist Take on Three Multiannual Financial Frameworks}

\section{Pierre Georges Van Wolleghem}

INAPP, Italian National Institute for the Analysis of Public Policies, Rome, Italy

\section{Abstract}

This article investigates the trajectory the EU's policy on the integration of migrants has followed in approximately 20 years of its existence. Drawing upon neofunctionalist theory, it aims to assess whether the EU's role in the matter is expanding or stalling. Empirically, this article considers the succession of financial schemes explicitly tackling integration, in light of the fact that they constitute valuable indicators of the direction, breadth and stringency of a given policy. I therefore compare the funds allocated to integration in the 2007-2013, 2014-2020 and 2021-2027 multiannual financial frameworks. I find that the process underway is dual: whilst the EU's role is clearly receding in terms of substantive policy points, it appears to be widening on the procedural side.

\section{Keywords}

migration, integration, multiannual financial framework, neofunctionalism, EU funds 


\section{Introduction}

Over the past twenty years, the European Union (EU) has developed a policy aimed at integrating migrants in their receiving societies. It was first advanced without a legal competence, through a patchwork of soft law instruments. The entry into effect of the Treaty of Lisbon in 2010 formally conferred on the EU a role in the matter, thus suggesting an expansion of its integration policy. The start, last year, of the negotiations for the EU's forthcoming multiannual financial framework seemed to confirm a tendency towards the consolidation of the policy. Yet, a careful analysis unravels a more nuanced process, which poses the question of the direction the EU's policy is going. This article investigates the trajectory the EU's policy on the integration of third country nationals has followed thus far in order to assess whether the locus of policy-making in the domain is shifting towards the EU.

As migration has become a structural feature of European society, integration has gained central relevance, be it for migrants themselves or for the EU's economy as a whole. As Europe ages, the proportion of workers compared to that of pensioners shrinks, posing obvious problems in sustaining both the EU's economy and member states' social policies (European Commission, 2011). For several years now, immigration has been the main driver of population growth (Lanzieri, 2010; see also OECD, 2016). Projections show that influxes are not likely to cease in the near future. Yet, migrants face considerable obstacles on their path towards full labour market integration ${ }^{1}$, thus undermining the value they can add to the EU and to national economies. If EU member states wish to make the most of the potential migration holds, integration is a key issue and an issue that they seem to have acknowledged ${ }^{2}$.

When they gathered in 1999 in Tampere, Finland, to set the basis of the Area of Freedom, Security and Justice (AFSJ), the member states called immediately for a "more vigorous integration policy" to be put in place at the EU level (European Council, 1999). Indeed, as much as environment or transportation, immigration - and integration as one of its subsets - has transnational stakes, thus justifying the Union's action in the policy realm. However, no legal competence existed on the matter. A policy on the integration of migrants unfolded nonetheless, from the early 2000s up until the present day. Comprising a common conceptual framework relating to integration, networks of officials, benchmarks and funding opportunities, the policy took the shape of an ensemble of soft instruments, a patchwork of tools forming a fragmented but coherent framework. With the entry into force of the Treaty of Lisbon in 2010, the EU was endowed with a formal competence on integration. Although limited in scope, such a competence hinted at a plausible expansion of the policy in time, through the adoption of new policy instruments. Instead, the development of the policy in subsequent phases displays ambiguous signals as to whether it is expanding or shrinking. This article aims to answer the following question: where is the EU's policy on the integration of migrants heading? Is it moving towards a greater role for the EU or is the EU's intervention in the domain retrenching?

Whereas scholarship has focused on the effects of single EU outputs on national policies, and thus concentrated on single events, this piece of research conceives the EU's policy as a process. By linking the dots of its progressive development, it seeks to identify the trajectory this policy has followed over time. Drawing upon neofunctionalist theory, I seek to reconstruct the process that has led to today's integration policy at the EU level. I take as an indicator of policy dynamics the evolution of the funding structure for integration, as established by the

1 - There is quite a wealth of publications on the matter but see, inter alia, Castles et al., 2013.

2 - Realising the potential of migration has been a recurring topic at the EU level since at least 2003. See, for instance, $\operatorname{COM}(2003) 336$ final. 
succession of multiannual financial frameworks (MFFs). The passage from the 2007-2013 to the 2014-2020 MFF as well as the debate over the forthcoming 2021-2027 MFF offer a unique opportunity to compare different phases of development of the policy and assess whether its evolution is headed towards more or less EU involvement in integration policies. I find that the process at play is dual: whilst the EU's role consistently shrinks on substantive directions, it appears to be thriving on the procedural side.

The first section of the paper provides a brief review of the growing literature on the topic in order to refine this article's contribution to the debate. I also clarify the perspective endorsed in this article, namely, neofunctionalism. The second section indicates the epistemological choices made to characterise the process under scrutiny. It also outlines the method and technique at the basis of the findings presented. Sections 3 through 5 analyse each of the three MFFs in turn, providing a comparison of their specific features with the previous funding scheme. I also provide some context to underline some of the functional pressures exerted (e.g. the asylum crisis). Lastly, I conclude in the sixth section by taking stock of the findings and addressing the research question.

\section{Literature review}

Despite the fact that the first reference to an EU integration policy was made approximately 20 years ago, political scientists and public policy scholars have only recently started to consider it as a research object. Most of the scholarly attention to migrant integration policy has, thus far, focused on nationally and sub-nationally defined public policies, relegating the EU's intervention in this policy realm to a secondary aspect to be taken account of in a multilevel governance structure (Geddes and Achtnich, 2015; Scholten and Penninx, 2016). In contrast, the development of the Area of Freedom Security and Justice (AFSJ) has given rise to three different strands of study focusing on the EU level. The first one, mostly consisting of lawyers, stressed the potential conflicts between EU and national legal orders that the AFSJ, and the provisions relating to legal migration (and thus somehow concerning integration), could generate (Kostakopoulou, 2002a; Groenendijk, 2004; Murphy, 2009; Handoll, 2012). A second strand has concentrated on the effects of the provisions contained in the various Directives relating to legal migration, notably in the family reunification Directive (Oosterom-Staples, 2007; Groenendijk et al., 2007; Hailbronner, 2010), and in the long-term residence Directive (Halleskov, 2005; Kostakopoulou, 2002b). A third strand has developed whilst the policy, facing the reluctance of member states, has taken the shape of soft law instruments.". Whilst some scholars have studied the Commission's attempt to launch an Open Method of Coordination (OMC; Caviedes, 2004; Szyszczak, 2006; Velluti, 2007), others have studied the effects of the EU's outputs on national policies, notably with regard to the Common Basic Principles on integration (Mulcahy, 2011; Carrera and Faure Atger, 2011) and the European Integration Fund (Van Wolleghem, 2017; 2019).

On the other hand, little attention has been paid to the original pattern the policy as a whole formed. Although some EU and national officials who took part in the policy-making process over the 2000s have provided interesting factual elements, a wider theoretical perspective has been lacking (Urth, 2005; Pratt, 2015). Carrera (2008) has framed the whole policy as a "quasi-OMC", thus alluding to the coherent patchwork of soft law instruments. Van Wolleghem (2019a), for his part, has traced the process that led to the emergence of the EU's integration policy. However, these studies have proposed accounts that are either static or focused on a limited timespan; therefore, they have to date been unable to produce a dynamic analysis of 
the trajectory of the policy as whole. This is despite the fact that the persistence of the policy in time and the changes it seems to have undergone pose the pertinent question of the direction the policy is taking.

In order to understand these changes and hypothesise the policy's trajectory for the years to come, I borrow from neofunctionalist theory. Despite the vivid criticisms it has received over the years, particularly relating to its early formulations ${ }^{3}$, neofunctionalism proposes useful concepts for the analysis of European integration ${ }^{4}$. In this line of thought, European integration is understood as a process of gradual shift ${ }^{5}$ from political activities towards a new centre (Haas, 1958). It is characterised by diverse and multiple actors whose interaction leads to incremental decision-making (as opposed to grand designs or teleological dynamics), itself driven by marginal adjustments resulting from the unintended consequences of previous decisions (Niemann and Schmitter, 2009). Importantly, neofunctionalism also distinguishes between the depth and breadth of European integration; the former being a matter of degree to which a given issue is governed at the EU level, and the latter being a question of the scope of issues in which the EU has a say (Niemann, 2006). The purpose of this article is to capture the dynamics at play in the development of the EU's integration policy to assess whether we are witnessing a process of European integration. Therefore, I focus on the depth of the phenomenon; that is, the degree to which a particular policy realm becomes an EU matter, rather than on the breadth of the phenomenon (or how the EU gained competence on the matter in the first place). According to neofunctionalist orthodoxy, one would expect a process of spillover to take place, irresistibly leading to further European integration (Haas, 1958). Revised versions of the theory have, however, tended to reject the automaticity of spillover effects, hypothesising the existence of other responses and, notably, the reversibility of regional integration (Schmitter, 1970; 2004).

\section{Epistemological and methodological choices}

Capturing policy dynamics is a complex undertaking, in that the perspective from which it is observed has far-reaching consequences on the research design, choice of variables and methodology, and, of course, on research results (Capano and Howlett, 2009). The risk is therefore high that one sees a certain level of European integration in every policy in which the EU has a say. Epistemological choices, therefore, ought to be clarified in order to adequately grasp the essence of the phenomenon under study (Capano, 2009). While it is clear that the purpose of this article is to establish whether a process of integration of the policy in question is underway, it is less clear what is regarded as a case of European integration. European integration is generally understood as the expansion of the role of supranational institutions, but such an expansion may manifest in different ways. For the purpose of this article, I consider two main possible indicators of European integration. On the one hand, there is European integration in cases in which the Union acquires the ability to orientate member states' substantive policies.

\footnotetext{
3 - Early versions of Neofunctionalism were formulated by Haas (1958) and Lindberg (1963). They were subsequently criticised, especially by prominent intergovernmentalist scholar Moravcsik. Niemann's (2006, p. 12) opening line is quite revealing in this respect: "Neofunctionalism is the most refined, ambitious and criticised theory of integration". See Niemann and Schmitter (2009) for an overview of the criticisms addressed to the theory.

4 - The confusion in terms between "policy for the integration of migrants" and "European integration" is unfortunate. For the sake of clarity, the process whereby a policy is integrated in the EU sphere will systematically be referred to as "European integration" or "regional integration" while the integration of migrants may, in some instances, be simply referred to as "integration".

5 - Note though that this is a minimal definition of European integration. Haas (1958) originally theorized the end result of the process as well.
} 
On the other hand, I consider there is European integration when the Union is capable of altering procedural features in a way that either diminishes member states' discretion or increases the EU's.

From the methodological standpoint, the perspective endorsed implies choices as to the research object, which allows an empirical study of the policy's chronology. I consider the multiannual financial frameworks (MFFs), and the funds they cover, as indicators of the pace and direction of change. MFFs constitute the medium-term budget of the EU; they plan the spending of its resources for seven years in accordance with the EU's political priorities. Each MFF is then broken down into specific funds, each with their own priorities and spending rules. In this way, MFFs (and the funds they cover) indicate how, how much and when the EU is to intervene in a given policy field. The present research spans three MFFs: i) the 2007-2013 MFF, long concluded, and for which a wealth of documents is available; ii) the 2014-2020 MFF, which is still being implemented; and iii) the 2021-2027 MFF, which is still being negotiated and for which only the Commission's proposal is available. For each of these, I propose a comparison of the funds explicitly addressing the integration of migrants. Table 1 below summarises the main changes. I also underline elements of situational and financial context in order to outline the functional pressures exerted on the policy. 
Tab. 1 - Evolution of the EU's funding scheme for the integration of migrants

\begin{tabular}{|c|c|c|c|}
\hline Item & 2007-2013 MFF & 2014-2020 MFF & \begin{tabular}{|l|} 
2021-2027 MFF (COM \\
proposal)
\end{tabular} \\
\hline Fund name & $\begin{array}{l}\text { European Fund for the } \\
\text { Integration of third } \\
\text { country } \\
\text { nationals (EIF) }\end{array}$ & $\begin{array}{l}\text { Asylum, Migration } \\
\text { and Integration Fund } \\
\text { (AMIF) }\end{array}$ & $\begin{array}{l}\text { Asylum and } \\
\text { Migration Fund (AMF) }\end{array}$ \\
\hline \begin{tabular}{|l|} 
Scope of the fund \\
\end{tabular} & $\begin{array}{l}\text { Narrow, only } \\
\text { integration }\end{array}$ & \begin{tabular}{|l} 
Wide, with \\
safeguards for \\
asylum and \\
integration \\
\end{tabular} & $\begin{array}{l}\text { Wide, with no } \\
\text { safeguard }\end{array}$ \\
\hline $\begin{array}{l}\text { Targeting } \\
\text { principle }\end{array}$ & $\begin{array}{l}\text { Exclusive, only third } \\
\text { country nationals who } \\
\text { are not } \\
\text { beneficiaries of } \\
\text { international } \\
\text { protection }\end{array}$ & $\begin{array}{l}\text { Inclusive, non-EU } \\
\text { citizens }\end{array}$ & $\begin{array}{l}\text { Inclusive, non-EU } \\
\text { citizens with focus on } \\
\text { short-term } \\
\text { integration }\end{array}$ \\
\hline $\begin{array}{l}\text { Amounts (as per } \\
\text { original legal act) }\end{array}$ & 825 million & 3,137 million & 10,415 million \\
\hline $\begin{array}{l}\text { Of which explicitly for } \\
\text { integration }\end{array}$ & 825 million (100\%) & 478 million (15.2\%) & 0 \\
\hline $\begin{array}{l}\text { Co-financing } \\
\text { principle (EU's share) }\end{array}$ & $\begin{array}{l}50 \% \\
75 \% \text { maximum } \\
\end{array}$ & $\begin{array}{l}75 \% \\
90 \% \text { maximum } \\
\end{array}$ & $\begin{array}{l}75 \% \\
100 \% \text { maximum } \\
\end{array}$ \\
\hline $\begin{array}{l}\text { Implementation } \\
\text { method (as per legal } \\
\text { act) }\end{array}$ & \begin{tabular}{|l|}
$93 \%$ shared \\
management \\
$7 \%$ direct/indirect man- \\
agement
\end{tabular} & $\begin{array}{l}88 \% \text { shared } \\
\text { management } \\
12 \% \text { direct/indirect } \\
\text { management }\end{array}$ & $\begin{array}{l}60 \% \text { shared } \\
\text { management } \\
40 \% \text { shared or } \\
\text { direct/indirect } \\
\text { management } \\
\end{array}$ \\
\hline $\begin{array}{l}\text { Substantive policy } \\
\text { directions }\end{array}$ & \begin{tabular}{|l|} 
High, attempt to initiate \\
convergence through \\
implementation of the \\
CBPs and some level of \\
coercion/incentive \\
\end{tabular} & Low, widely defined & Low, widely defined \\
\hline $\begin{array}{l}\text { Procedural } \\
\text { constraints }\end{array}$ & $\begin{array}{l}\text { Low, high discretion of } \\
\text { central } \\
\text { governments, } \\
\text { weak partnership prin- } \\
\text { ciple, no } \\
\text { additionality } \\
\text { principle. }\end{array}$ & $\begin{array}{l}\text { Medium, stronger part- } \\
\text { nership } \\
\text { principle, weak } \\
\text { additionality } \\
\text { principle }^{6}\end{array}$ & $\begin{array}{l}\text { High, reinforced part- } \\
\text { nership } \\
\text { principle, weak } \\
\text { additionality } \\
\text { principle }^{7}\end{array}$ \\
\hline
\end{tabular}

Source: The Author

6 - Featured in Regulation 514/2014/EU, article 3(1), which reads “The Specific Regulations shall provide support, through national programmes, Union actions and emergency assistance, which complements national, regional and local intervention". No control mechanism is provided for in this respect, making the principle almost insignificant. 7 - Featured in COM(2018) 471 final, article 7(1), which reads "Support provided under this Regulation shall complement national, regional and local intervention, and shall focus on adding value to the objectives of this Regulation." 
This article borrows mostly from case-study methods, a heterogeneous set of approaches that, however, have in common the intensive study of a bounded system (or systems) over time through detailed data collection and analysis (see Creswell, 2007, for an interesting account). As for the technique used, the findings presented rely on document analysis to map the evolution of the EU's integration policy, from the outset to the present day. Data was obtained via the EU Commission's various platforms from which official documents were downloaded. They mostly consist in Communications from the Commission (and technical appendices), European Council Conclusions and adopted pieces of legislation. From the bulk of documents retrieved, I have focused my attention on those specifically concerned with budget matters. For ease of reading, only the most relevant documents are cited in the main text.

\section{The beginning of a policy and the 2007-2013 MFF}

\section{A narrow policy space for the EU}

Further to the entry into force of the Treaty of Amsterdam and the forthcoming creation of the Area of Freedom Security and Justice (AFSJ), the programme member states agreed upon in Tampere provided the European Commission with a mandate to develop an integration policy. Despite member states' commitment in principle, implementing the "more vigorous integration policy" impetus proved harder than expected (Urth, 2005; Van Wolleghem, 2019a). Notwithstanding, the general context was somehow favourable to the emergence of an integration policy. Even though migration was mainly framed as a security issue ${ }^{8}$, all the more so after the attacks on the Twin Towers in 2001, the social inclusion paradigm pervaded the EU policies of the time, to the point that it was enshrined in EU primary law (Vanhercke, 2012; Mathieson et al., 2008). Accordingly, migrants appeared as a group at risk of exclusion that should therefore be the object of specific attention. Integration had already been on the agenda of most member states since the late 1980 s/early 1990 s $^{9}$, such that the context at the national level was favourable to integration policy too. With a policy space available and a window of opportunity swinging open, the conditions were met to develop an integration policy at the EU level. But member states were resistant when it came to moving forward formally, notably with the adoption of Directives, thus showing that, if there were to be an EU integration policy, the policy space available for it would be very narrow.

The policy took shape thanks to the interaction of three conditions ${ }^{10}$. Firstly, to circumvent member states' reluctance, an integration policy would necessarily display great flexibility; soft law thus became the best alternative to normal policy instruments (notably Directives). Secondly, the policy had to pass from national agendas to the EU's agenda. The succession of several Presidencies of the Council with similar preferences proved successful in transferring these preferences to the EU level. Of course, such intent does not always pay off since policies or national agendas are in competition with others and not all of them end up on the EU agenda. But because any initiative in this domain necessarily involved soft law - so that member states would have the possibility to adopt a text without ever having to implement it - no member state had an interest in standing in the way of adoption and breaking the culture of consensus that reigns in the Council (see Aus, 2008, for an interesting example). Lastly, the third condition consisted in the readiness of the Commission to occupy a policy space without ever impinging on member states' exclusive competence. In so doing, the Commission systematised and transformed the progress made in (soft) policy instruments.

8 - In this respect, see Bigo, 1996; 2002; Guiraudon, 2003; Huysmans, 2000.

9 - The list of publications in this respect is rather long. See inter alia Schnapper (1994) and Wischenbart (1994).

10 - This paragraph summarises some of the findings presented in Van Wolleghem (2019a). 


\section{The European Integration Fund: EU money for EU principles?}

It is clear from the foregoing that the space for an EU integration policy was very narrow. In spite of this, a number of policy instruments were adopted. The most important ones in the first years were: i) the National Contact Points on Integration (NCPI), created in 2002 as a network of officials for the exchange of information and practices amongst member states; ii) the Common Basic Principles on integration (CBPs), adopted in 2004 as a set of 11 shortworded non-binding principles aimed at guiding member states policies; and iii) the European Integration Fund (EIF) ${ }^{11}$, adopted in 2007 as a fund of approximately $€ 825$ million to be spent over the period 2007-2013. The NCPI, the CBPs and the EIF were strongly interconnected. The NCPI functioned as a forum on which the Commission could rely to develop and discuss new initiatives at the EU level before starting the official procedure (Urth, 2005). This is where the CBPs were first presented as well as the first ex-ante impact assessment and the draft Decision relating to the European Integration Fund. The CBPs were thought of as the conceptual framework on which further policy instruments relating to integration should be based. Lastly, the EIF provided for systematic funding opportunities to support national policies implementing the CBPs. The implementation of these principles was consistently encouraged through a mix of "soft obligations" and financial incentives. For soft obligations, member states would need to state how and the extent to which they would implement the principles in their multiannual spending programme. Likewise, some priorities, albeit vaguely defined, would be mandatory but broad enough to fit different ambitions (Van Wolleghem, 2019a). As for financial incentives, EU money would support projects addressing a set of specific priorities by increasing its co-financing share from 50 percent to 75 percent $^{12}$. In summary, the EIF had a strong convergence ambition; it provided a series of substantive policy points and encouragements for the member states to follow them.

However, without a strong foothold on integration matters at the EU level, the adoption of a fund that would consistently enforce a European view of integration was unlikely. The absence of a clear legal basis would necessarily imply a limited role for the Commission in the definition of the priorities, as well as very limited control mechanisms over member states' implementation choices. Accordingly, it would be up to the state to decide whether or not to use EU funding to give effect to the $\mathrm{CBPs}^{13}$. As the Decision establishing the EIF reads:

The general objective of the Fund is to support the efforts made by the Member States in enabling third-country nationals of different economic, social, cultural, religious, linguistic and ethnic backgrounds to fulfil the conditions of residence and to facilitate their integration into the European societies (Decision 2007/435/EC, article 2; emphasis added).

From the outset, the EIF was thus placed in a limbo between the exclusive national competence and the European framework. Even though the CBPs were designed so that they would focus on key areas and shared problems rather than on national practices in order to increase their acceptability (Pratt 2015), and even though they were adopted at the unanimity of the member states, their practical implementation as per Multi-Annual Programmes was found to be underwhelming (Carrera and Faure Atger, 2011). Similarly, evidence regarding the Annual Programmes shows that implementation of the priorities set at the EU level was very modest, despite the existence of financial incentives (Van Wolleghem, 2017).

11 - Decision 2007/435/EC.

12 - The financial incentive only applied to the member states not eligible for the cohesion fund. Member states covered by the cohesion fund would receive 75 percent by default. See Decision 2007/435/EC for more on this.

13 - In her study, Mulcahy (2011) finds that the CBPs had no effect whatsoever on member states' integration policy. 
Fig. 1 - Implementation of EU indications by the member states in percent of total funding, by financial incentive, mean percentage and standard deviation, 2007-2013

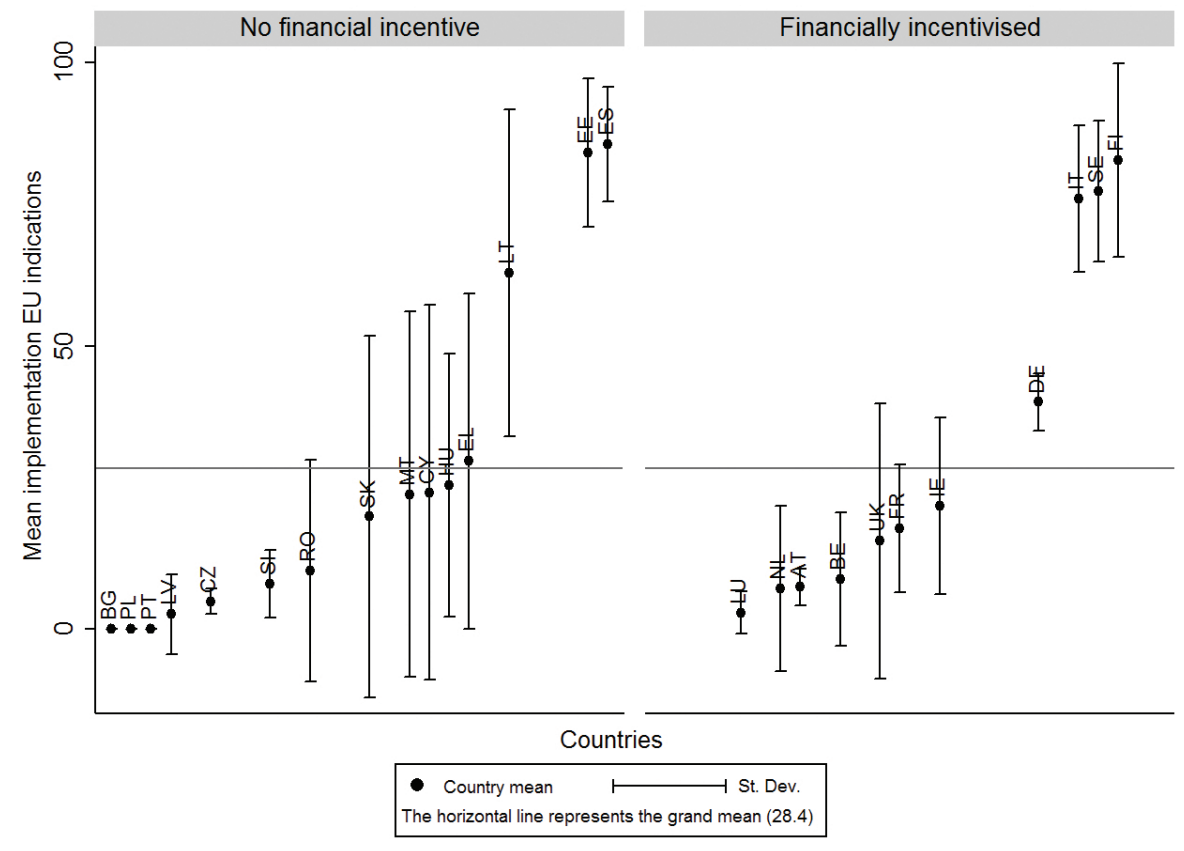

Source: Van Wolleghem, 2017, p. 1131

Figure 1 displays the means and standard deviations of member states' intention to implement the priorities set by the European Commission ${ }^{14}$, as per their annual programmes, for the years 2007-2013. The values are expressed in percentage of total funding so that, for instance, Germany planned to use, on average, about $40 \%$ of its total allocation to address EU priorities whilst Poland did not intend to address them at all ${ }^{15}$. Note that some member states were financially incentivised to address these priorities (on the right-hand side of the figure) whilst the member states eligible for the cohesion fund were not (on the left-hand side). In total, a stark 28.4 percent of the total funding over the seven years of implementation and across countries actually planned to tackle EU indications. The financial incentive provided by the EU proved incapable of dragging member states' preferences towards the indications set at EU level.

On the procedural side, the EIF, despite being designed on the model set by structural funds, hardly resembled the latter. Indeed, it would grant the Commission control mechanisms to ensure lawful and sound financial management, but national governments would still enjoy wide discretion as to how to spend their allocations. The principles-now well establishedintroduced with the reform of the EU's cohesion policy in 1988 (Bachtler and Mendez, 2007) would have little or no bearing. This meant that no additionality principle was provided for, so that member states could substitute national funding with their EIF allocations. Likewise, the partnership principle, which associates a series of actors to the management of the funds,

14 - The priorities in question were established in Commission Decision C (2007) 3926 final.

15 - See Van Wolleghem (2017 and appendix) for more detail and calculation methods. 
was made optional in the case of the EIF. As a matter of fact, most member states considered the principle as a one-off consultation on the occasion of the drafting of the Multi-Annual Programme (Carrera and Faure Atger, 2011).

All in all, it appears that the member states were capable of retaining a firm grip on the use of the fund and on the policy altogether. The end of the 2007-2013 financial framework and the entry into effect of the 2014-2020 financial framework opened up on a new phase of policy development that offers the possibility to compare the design of the EU's intervention on integration matters in time and see whether its role has improved or receded (Table 1 above summarises the most relevant changes).

\section{Supporting member states policies and the 2014-2020 MFF}

\section{A legal competence on integration}

The EIF was created as a means to "support member states' policies", as the Decision establishing the fund read ${ }^{16}$, but was supposed to give effect to the Common Basic Principles on integration, a set of principles aimed at framing member states' policies in order to, eventually, reach some level of convergence (Mulcahy, 2011). The entry into force of the new financial framework brought to bear its sequel, the Asylum, Migration and Integration Fund ${ }^{17}$ (AMIF). Before exploring its features, some preliminary remarks are in order as important changes occurred between the adoption of the EIF and the adoption of the AMIF.

First of all, the overall institutional framework had changed. The Treaty of Lisbon, which entered into effect in 2010, finally provided a legal basis for the EU's policy on integration ${ }^{18}$. However, such a legal basis was limited to a single paragraph that circumscribed the EU's action to providing "incentives and support for the action of member states" ${ }^{19}$, thus constraining the scope of a sound EU integration policy. Another major change, introduced by the treaty of Lisbon, is the change in voting rules that ended the legal migration special regime. Decisions relating to integration would no longer be taken at the unanimity of the member states ${ }^{20}$ but $^{2}$ at qualified majority voting.

The question that arises is whether these changes translate into a more consistent EU integration policy or the other way around. Considering the Treaty of Lisbon, the introduction of a clear reference to integration may be construed as a further step towards a stronger EU integration policy whereas the limited scope of this very same provision may be read as a step backwards. More importantly, the changes in the overall structure of the migration funds send ambiguous signals, both money-wise and priority-wise.

\section{The Asylum, Migration and Integration Fund: easing spending as a new priority}

The EIF's evaluation reports have consistently underlined the complexity of the fund's spending rules (Ramboll, 2011; 2018b). On the one hand, the administrative burden was deemed too heavy compared to the amounts distributed; on the other, the existence of two funds with

\footnotetext{
16 - Decision 2007/435/EC, article 2.

17 - Regulation 514/2014/EU.

18 - Integration was first mentioned in primary law in the Constitutional Treaty. It notably excluded legal harmonisation in this domain. The Constitutional Treaty, however, was never adopted, making the treaty of Lisbon the first official reference to integration in primary law.

19 - Article 79(4) TFEU. Note that the Constitutional Treaty, rejected in 2005, featured the same provision.

20 - Even though no legal basis was provided, measures on integration were adopted on the basis of article 63(3)

(a) TEC relating to conditions of entry and residence, a very thin legal basis used in a "creative" manner, to borrow Handoll's wording (2012, p. 45).
} 
overlapping, yet mutually exclusive targets, made its use difficult (see below). In response to these issues, the structure of the funds for the EU's migration policy was overhauled with the 2014-2020 MFF. Whereas the previous financial framework counted four distinct funds-each for a specific item, namely borders, refugees, return and integration-with clear allocations for each of them, the 2014-2020 financial framework merged them into a unique fund ${ }^{21}$, thus granting more flexibility in its use on the part of the member states (Malmström, 2014; Ramboll, 2018a; Westerby, 2018). In order to ensure flexibility would not translate into too much focus on one item or another, safeguards were introduced. For integration, it was provided that a minimum of 20 percent of the fund be earmarked for the integration of migrants. This safeguard opened the possibility that less funding be dedicated to integration than with the EIF. Considering that the AMIF initially ${ }^{22}$ amounted to $€ 3,137$ million, in the event that every member state would decide to limit their allocations to integration to the 20-percent threshold, the amount that would go to integration would be about $€ 478$ million $^{23}$, slightly more than half as much as the EIF. Going over this minimum would then be up to the state and how it intended to distribute its allocation between integration, asylum, solidarity and return ${ }^{24}$.

Furthermore, the benchmark for comparison in this situation is not the EIF but the EIF together with a part of the European Refugee Fund (ERF). The EIF was a fund strictly targeting the integration of third country nationals who are not beneficiaries of international protection. Instead, the ERF was dedicated to a wide range of interventions relating to asylum, comprising the integration of beneficiaries of international protection. With a total of $€ 628$ million, it is hard to appraise the share of the ERF that was actually used by the member states to ease the integration of beneficiaries of international protection ${ }^{25}$ and thus that which should be added to the EIF to build a proper benchmark against which to compare the AMIF minimum amount for integration. The fact remains that the AMIF presents the clear opportunity to stick to a minimum of $€ 478$ million dedicated to integration.

The data available thus far shows that member states exceeded this threshold. The AMIF interim evaluation report calculates that around 32 percent of the fund was used to address the specific objective "Integration/legal migration" over the period 2014-2017 (Ramboll, 2018a, p. 33). This summary figure, however, hides differences between groups of countries with, for instance, the UK and Ireland displaying an average of 24 percent of their allocations to the issue, and Italy, Greece and Malta around 22 percent. Greece obtained a derogation to the 20-percent minimum allocation rule and foresaw a sheer 12.5 percent of its total to integration and legal migration (Westerby, 2018, p. 22).

\footnotetext{
21 - Border management was not included in the AMIF. It was made part of the Internal Security Fund, another innovation of this financial framework. in this domain. The Constitutional Treaty, however, was never adopted, making the treaty of Lisbon the first official reference to integration in primary law.

22 - I write "initially" because it was considerably increased during the asylum crisis in order to tackle the emergency. This brought the total funding for the $2014-2020$ period to $€ 6,888$ million (Ramboll, 2018a).

23 - The amount calculated here is lower than 20 percent of the AMIF's total amount ( $€ 3,137$ million). This is because an accurate calculation in this respect shall not consider the total AMIF amount but the total that goes to the states for asylum, integration and return ( $€ 2,392$ million, or 88 percent of the total) since 12 percent of the fund is directly or indirectly managed by the Commission. See next paragraph.

24 - It should also be noted, as Westerby (2018, p. 22) points out, that the minimum percentages to be dedicated to integration or asylum are required to be allocated as per national programme but they need not be actually spent. 25 - The reports available on the implementation of the ERF mention the share of projects that addressed integration but not the share of funding that addresses integration. Yet, there may be a significant discrepancy between the former and the latter. According to E\&Y (see European Commission, 2018, p. 69), the share of projects that addressed integration over the period 2011-2013 was 42 percent whilst the greatest share regarded reception conditions with $47 \%$ of all the actions undertaken.
} 
Beyond the amounts provided for, another aspect is fundamental to assess where the EU integration policy is heading: the definition of priorities. With the EIF, there was a clear attempt to generate convergence through the definition of principles as its use was supposed to contribute to the implementation of the CBPs. Numerous were the references in the EIF Decision directly or indirectly referring to the implementation of the CBPs. Resultantly, the EIF's evaluation reports also emphasised the priorities addressed by member states while spending EU resources (Ramboll, 2011; 2013). No such an attempt appears to have been at the basis of AMIF's design. Instead, the AMIF only includes loose references to substantive policy points. If one considers as an example the attention paid to the CBPs, the only direct reference to them is Recital (20) of Regulation 516/2014/EU, even though indirect references may be seen in the reading of article 9 that specifies the kind of integration measures that the fund supports. Consequently, CBPs do not feature in member states' spending programmes or in their reporting activities and nor in monitoring and evaluation activities ${ }^{26}$. This translates into less attention being paid to the common priorities established at the EU level for integration and more attention to member states' priorities. This does not mean that the CBPs are ignored altogether, as they may be part of the shared beliefs that orientate member states' policy making ${ }^{27}$, but it does mean that they lose visibility, which makes it hard to appraise whether they are being followed or even heeded.

On the procedural side, significant changes occurred in the passage from the EIF to the AMIF. The principle of partnership was significantly reinforced with the AMIF. Originally, the partnership principle was introduced by the Commission with the reform of the EU's cohesion policy in 1988 (Bachtler and Mendez, 2007) and provided for the participation of national, supranational, but especially subnational actors, in the design and implementation of programmes adopted in the framework of said policy. As already mentioned, the EIF comprised a partnership principle in its design, albeit a much less stringent one. Because the principle, as formulated in the EIF, left great room for manoeuvre regarding the choice of the stakeholders to be associated and the phase of the policy cycle in which they would participate, it rather consisted in an invitation to consult bodies other than governments in the management of the fund $^{28}$. Differently, the AMIF features a stronger partnership principle, which forces the association of subnational bodies to the "preparation, implementation, monitoring and evaluation of national programmes" 29 . In so doing, it consistently decreases central governments' grip on the management of the fund.

Lastly, yet importantly, the AMIF has greatly increased the share of the fund the EU Commission can use with some level of discretion. According to financial Regulations ${ }^{30}$, EU money may be spent following three methods: i) shared management: the member states spend, the Commission controls; this is the management method used for member states' allocations; ii) di-

26 - One report has been published thus far, that of Ramboll (2018a) on the midterm evaluation of the AMIF in the member states concerned. It does not mention in any place the Common Basic Principles. As for national programmes, a survey of those readily available online in the English language shows they do not explicitly refer to the CBPs.

27 - For instance, in Radaelli's (2003, p. 30) conception of Europeanisation, it is likely that the ways of conceiving of a problem or its solution be defined and consolidated at the EU level and then pervade the logic of domestic discourse, identities and political structures. The study realised by Mulcahy and published in 2011 seems to demonstrate the absence of learning processes with regard to the CBPs at the time (Mulcahy, 2011).

28 - For more detail, see Van Wolleghem, 2019a, p. 115.

29 - See article 12, Regulation 514/2014/EU. The provision also specifies that 'the composition of the partnership may vary at different stages of the programme'.

30 - For instance, in Radaelli's (2003, p. 30) conception of Europeanisation, it is likely that the ways of conceiving of a problem or its solution be defined and consolidated at the EU level and then pervade the logic of domestic discourse, identities and political structures. The study realised by Mulcahy and published in 2011 seems to demonstrate the absence of learning processes with regard to the CBPs at the time (Mulcahy, 2011). 
rect management: the Commission (or EU agencies) spends directly; iii) indirect management: the Commission delegates by entrusting budget implementation to third parties (other than member states in the case at issue). Whilst shared management puts the member states in charge, so to speak, direct and indirect management confers on the Commission greater room to express its preferences, through the adoption of its annual work programmes, within the limits set by specific funds' Regulations. With regard to the EIF, 7 percent of the total funding ( $€ 58$ million) was to be spent through direct management for Community actions; i.e. transnational projects or actions of interest to the Community as a whole. The AMIF considerably extended both the scope and width of the direct and indirect spending method. The Regulation earmarked 12 percent of the total ( $€ 385$ million) to be spent for Union actions, emergency assistance, the European Migration Network and technical assistance of the Commission.

Everything considered, it appears that the AMIF has initiated a dual process of European integration characterised by less substantive directives but more procedural pressure and more room for the Commission's preferences. Pursuing the objective of easing implementation and increasing spending (Malmström, 2014; Ramboll, 2018a; Westerby, 2018), the AMIF has shed most of the EIF's substantive objectives, thereby reducing its ambition to generate convergence. At the same time, the new fund has increased both the EU's and subnational bodies' weight in the management of integration funding. This logic appears to have been accentuated with the outbreak of the asylum crisis.

\section{The short-term consequences of the Asylum crisis}

The sudden increase in asylum cases over the years 2014-2016 put the EU's ability to propose a concerted response to the test. The uneven distribution of inflows and the unanswered calls for more solidarity ${ }^{31}$ generated tensions among member states. In the midst of the crisis though, the AMIF was topped up with significant resources to face the emergency ${ }^{32}$. By the end of 2017, this sum amounted to $€ 6,888$ million, a 120 per cent increase compared to the original budget. Interestingly, the decision taken in the passage from the 2007-2013 to the 2014-2020 MFF to merge the funds dedicated to integration and asylum, combined with the response to the asylum crisis, has had the unintended effect of increasing the resources allocated to integration altogether. With the increase of the AMIF, an additional $€ 2,305$ million was made available for the integration of third country nationals (irrespective of their protection status). Such an increase was, however, lower than the increase dedicated to asylum (solidarity, relocation and reception), such that, even if the absolute amount for integration increased, its relative importance decreased to 19 percent of the total funding ${ }^{33}$.

At the same time, the percentage of funding at the disposal of the Commission under direct and indirect management-thus with some level of discretion-was increased to 22 percent of the new total (that is, $€ 1,491$ million instead of the 12 percent originally allocated). A good share of the amount at the Commission's disposal served to fund the emergency assistance $(€ 1,029$ million, or 15 percent of the total funding) but significant resources were attributed to Union actions (€462 million, some 7 percent of the total). Unfortunately, the data available does not allow a disaggregation of the figure per item but it appears that around 76 percent of the total amount spent for Union actions covered either legal migration/integration or returns ${ }^{34}$.

31 - See for instance the failure of the Commission's proposal to create a refugee quota system (Zaun, 2017) and the relative failure of the temporary relocation mechanism (Ortensi et al., 2018).

32 - See SWD (2018) 339 final.

33 - Ibid., p. 19.

34 - Ibid., p. 21. 
In summary, the new structure of EU migration funding introduced with the 2014-2020 MFF, together with the response to the asylum crisis, resulted in both more resources for integration and more resources to be spent at the Commission's initiative. This incremental development seems to have been followed up with the Commission's proposal for the 2021-2027 MFF.

\section{Mainstreaming integration and the 2021-2027 MFF}

\section{The medium-term consequences of the asylum crisis}

The asylum crisis has generated tensions between member states which are, paradoxically, likely to facilitate the emergence of a consensus on the need for more funding for an integration policy. More precisely, member states' reluctance to manifest solidarity by relocating migrants in their territory (Zaun, 2017; Ortensi et al., 2018) may very well translate into them preferring financial solidarity ${ }^{35}$. In this perspective, the Commission's proposal for a renewed MFF brings about two novelties: a significant increase of migration funds and of the AMIF's substitute, the Asylum and Migration Fund (AMF - see below); and an attempt to mainstream the integration of migrants by including it as a clear objective for the European Social Fund Plus (ESF+) and the European Regional Development Fund (ERDF).

Starting with the latter point, the European Social Fund (ESF) has always, more or less explicitly, concerned migrants as a group prone to exclusion and whose labour market integration should be facilitated. However, ESF resources have never been either distributed to member states in accordance with their share of foreign residents or specifically targeted at third country nationals (CSES, 2011). With the forthcoming MFF, these two aspects are likely to change. On the one hand, the MFF provides for a share of the ESF+ and ERDF to be distributed according to the number of third country nationals residing in member states' territories. More precisely, as the proposal reads, to member states' respective allocation should be added "a premium of $€ 400$ per person per year, applied to the population share of the region of net migration from outside the EU to the Member State since 1 January 2013"36. On the other hand, the MFF provides for the ESF+ to explicitly target third country nationals. Namely, the Commission's proposal foresees a distinction in roles between the ESF+, aimed at migrants' medium and long-term integration, and the AMF, aimed at supporting early integration measures ${ }^{37}$. That said, the ESF+ proposal does not compel member states to earmark the share of their allocation they will dedicate to integration, thus losing the ability to ascertain a share of the ESF+ to be actually used for migrant integration ${ }^{38}$. In light of the foregoing, the mainstreamed approach to integration as proposed by the Commission does not seem to constitute an expansion of the EU's integration policy as of yet.

\section{The Asylum and Migration Fund: a fund for integration?}

Altogether, the 2021-2027 MFF, as drafted by the Commission, foresees a significant increase of funds for migration (2.6 times more than with the 2014-2020 MFF), thus indicating a shift in EU priorities, at least from the Commission's point of view ${ }^{39}$. With respect to the AMF, the

35 - With, on the one hand, the Visegrád Group coalition against relocation and, on the other hand, the pressure exerted by Germany and Austria against secondary movements, the motto seems to be: anything but relocation (see Van Wolleghem, 2019b). Financial solidarity in this respect appears to be a plausible alternative to practical solidarity. 36 - See COM (2018) 375 final.

37 - See COM (2018) 471 final.

38 - See COM (2018) 382 final, article 7(3).

39 - Over the years, the EU's budget has stabilised at around 1\% of the EU's GDP. According to forecasts, it should amount to about 1.11\% of the EU's GDP for 2021-2027 (COM (2018)321 final, p. 24). Given such stability, the increase of the amounts dedicated to migration policies necessarily implies significant reductions in other policy fields, such as, for instance, the Common Agricultural Policy or the Cohesion policy. 
Commission has proposed a total of $€ 10,415$ million dedicated to asylum, migration and integration. Whereas the overall structure set with the previous MFF is replicated with the AMF, the new fund somewhat reshuffles the cards by blurring the distinction between management methods. The AMIF provided a clear split between national programmes, to be spent through the shared management method (88 percent of the fund), and actions at the initiative of the Commission, following a direct or indirect management method (12 percent). The AMF, as put forth by the Commission ${ }^{40}$, proposes that 60 percent of the total amount ( $€ 6,249$ million) be implemented under shared management; the remaining 40 percent would be allocated to a so-called "thematic facility" implemented through a mix of shared and direct/indirect management. It is not clear as of yet how this mix will operate in practice but, considering the trend established in the course of the two previous MFFs, an increase of the percentage allocated under the direct/indirect method compared to the AMIF is likely. If it were not so, there would, at any rate, be an increase of the absolute sum allocated in this manner, given the increase of the total amount.

Another significant change rests with the absence of any safeguard as to the use of money between the different strands of the fund, thus even questioning the integration objective of the AMF. The AMIF set a bottom limit whereby at least 20 percent of member states' allocations should tackle integration and another 20 percent asylum. In its pursuit of greater flexibility, the AMF proposal does not replicate these thresholds. This is a significant step backwards for the development of an EU integration policy in its own right, as it further accentuates the EU's withdrawal from substantive policy points by taking it to a whole new level.

From the procedural standpoint though, the discretion enjoyed by central governments is further reduced through the reinforcement of the partnership principle, now completely aligned with the structural funds. In fact, it is not provided for in the AMF proposal itself but higher up, in the umbrella Regulation that covers the provisions common to all the structural funds ${ }^{41}$. As it stands in the Commission's proposal, the principle explicitly designates the range of actors necessary to constitute the minimum partnership where the AMIF vaguely referred to "relevant authorities and bodies" 42 . These actors are: urban and public authorities; economic and social partners; relevant bodies representing civil society. They shall be involved through a Partnership Agreement, drafted together with national governments and submitted to the Commission for approval, and participate in the preparation and implementation of programmes.

The forthcoming MFF was presented by the EU Commission in May 2018. It is still a proposal and negotiations could still lead to significant alterations, so no conclusion can be drawn as of yet. It remains that the proposal put forth by the Commission, if it grants more discretion to the Union for migration policy-making as a whole, marks a significant step backwards for an EU integration policy in its own right.

\section{Conclusion}

Twenty years after the first reference to an EU integration policy, this article has aimed to shed light on the trajectory this policy has followed thus far. If the need for integration policies is hardly debatable, the role that the EU should have in this respect is more delicate a question. The creation of a common immigration policy with the treaty of Amsterdam eluded the

40 - See COM (2018) 471 final, articles 8 and 9.

41 - See COM (2018) 375 final.

42 - See Regulation 516/2014/EU. 
question: integration of migrants was not mentioned in EU primary law. This did not prevent member states from calling for a more vigorous integration policy at the EU level on the occasion of the Summit in Tampere in 1999. Thereafter, the Commission set a policy programme in motion that encountered strong resistance on the part of the member states: if they agreed to collaborate in principle, giving effect to their commitment proved a harder task. A policy on integration unfolded nonetheless.

Drawing on neofunctionalist theory, this article reconstructs the process that has led to today's integration policy at the EU level. I have notably focused on the financial schemes explicitly designed for the integration of migrants, in light of the fact that they constitute valuable indicators of the direction, breadth and stringency of a given policy. The passage from the 20072013 to the 2014-2020 MFF as well as the debate over the forthcoming 2021-2027 MFF offer a unique opportunity to compare the different phases of development of the policy and assess whether its evolution heads towards a deeper level of European integration. Starting with the 2007-2013 Multiannual Financial Framework (MFF), which gave birth to the first European Integration Fund (EIF), I have shown that the EU has displayed a clear attempt to generate convergence through the design of a fund intended to implement the Common Basic Principles on Integration. The passage from the 2007-2013 MFF to the 2014-2020 one has brought about significant change. Whilst substantive policy directives largely faded with the Asylum, Migration and Integration Fund (AMIF), procedural developments have increased the importance of subnational bodies and that of the EU, much to the detriment of national governments' discretion. In addition, the share of the fund the Commission is able to use with some level of discretion significantly increased. With the 2021-2027 MFF under negotiation, it is still too soon to ascertain the direction the EU's integration policy is actually taking. The proposal put forth by the Commission, however, seems to confirm the tendency initiated with the AMIF; that of dissociating substantive and procedural aspects with the former being almost entirely removed and the latter gradually reinforced. Likewise, the share of the fund to be used at the Commission's initiative would appear set to increase yet again. Accordingly, a likely scenario for the near future would see the EU's integration policy merged with the larger migration policy. Whilst the EU would lose the capacity to ascertain some of the funding going to integration, it would gain stronger procedural power over the entire migration financial scheme.

\section{Bibliography}

Aus, J. P. (2008). The Mechanisms of Consensus: Coming to Agreement on Community Asylum Policy. In D. Naurin \& H. Wallace (Eds.). Unveiling the Council of the European Union: Games Governments Play in Brussels (pp. 99-120). Basingstoke: Palgrave Macmillan.

Bachtler, J., \& Mendez, C. (2007). Who Governs EU Cohesion Policy? Deconstructing the Reforms of the Structural Funds. JCMS: Journal of Common Market Studies, 45(3), 535-564. https://doi.org/10.1111/j.1468-5965.2007.00724.x

Bigo, D. (1996). Polices En Réseaux: L'éxpérience Européenne. Paris: Presses de la Fondation nationale des sciences politiques.

Capano, G. (2009). Understanding Policy Change as an Epistemological and Theoretical Problem. Journal of Comparative Policy Analysis: Research and Practice, 11(1), 7-31. http://doi.org/10.1080/13876980802648284 
Capano, G. \& Howlett, M. (2009). Introduction: The Determinants of Policy Change: Advancing the Debate. Journal of Comparative Policy Analysis: Research and Practice, 11(1), 1-5. https://doi. org/10.1080/13876980802648227

Carrera, S. (2008). Benchmarking Integration in the EU: Analyzing the Debate on Integration Indicators and Moving It Forward. Gütersloh: Bertelsmann Foundation.

Carrera, S. \& Faure Atger, A. (2011). Integration as a Two-Way Process in the EU? Assessing the Relationship Between the European Integration Fund and the Common Basic Principles. Brussels: Centre for European Policy Studies.

Castles, S., de Haas, H. \& Miller, M. J. (2013). The Age of Migration. International Population Movements in the Modern World (5th ed.). Basingstoke: Palgrave Macmillan.

Caviedes, A. (2004). The Open Method of Co-ordination in Immigration Policy: A Tool for Prying Open Fortress Europe? Journal of European Public Policy, 11(2), 289-310. https://doi.org/10.1080/1350176042000194449

Creswell, J.W. (2007). Qualitative Inquiry and Research Design: Choosing among Five Approaches, 2nd edition. Thousand Oaks: Sage Publications.

CSES (2011). Evaluation of ESF Support for Enhancing Access to the Labour Market and the Social Inclusion of Migrants and Ethnic Minorities, Final Report. Kent: Centre for Strategy \& Evaluation Services. Retrieved from https://circabc.europa.eu/

European Commission (2011). The 2012 Ageing Report: Underlying Assumptions and Projection Methodologies. Brussels: European Commission.

European Commission (2018). Ex-post Evaluation of the European Refugee Fund 2011-2013 and Expost Evaluation of the European Refugee Fund Community Actions 2008-2010. Brussels: European Commission.

European Council (1999). Tampere European Council 15 and 16 October 1999, Presidency Conclusions.

Geddes, A. \& Achtnich, M. (2015). Research-Policy Dialogues in the European Union. In P. Scholten, H. Entzinger, R. Penninx, \& S.Verbeek (Eds.). Integrating Immigrants in Europe. Research-Policy Dialogues (pp.293-314). Amsterdam: IMISCOE Research Series.

Groenendijk, K. (2004). Legal Concepts of Integration in EU Migration Law. European Journal of Migration and Law, 6(2), 111-126.

https://doi.org/10.1163/1571816042885969

Groenendijk, K., Fernhout, R., van Dam, D., van Oers, R. \& Strik, T. (2007). The Family Reunification Directive in EU Member States: The First Year of Implementation. Nijmegen: Centre for Migration Law.

Guiraudon, V. (2003). The Constitution of a European Immigration Policy Domain: A Political Sociology Approach. Journal of European Public Policy, 10(2), 263-282.

https://doi.org/10.1080/1350176032000059035

Haas, E.B. (1958). The Uniting of Europe: Political, Social and Economic Forces, 1950-7. London: Stevens.

Hailbronner, K. (2010). Implications of the EU Lisbon Treaty on EU Immigration Law. Paper Prepared for the Transatlantic Exchange for Academics in Migration Studies, San Diego.

Halleskov, L. (2005). The Long-Term Residents Directive: A Fulfilment of the Tampere Objective of Near-Equality? European Journal of Migration and Law, 7(2), 181-202.

https://doi.org/10.1163/1571816054762205 
Handoll, J. (2012). Integration Policy in the European Union: The Question of Competence. In Y. Pascouau \& T. Strik (Eds.). Which Integration Policies for Migrants? Interaction Between the EU and Its Member States (pp. 15-50). Nijmegen: Wolf Legal Publishers.

Huysmans, J. (2000). The European Union and the Securitization of Migration. JCMS: Journal of Common Market Studies, 38(5), 751-777.

https://doi.org/10.1111/1468-5965.00263

Kostakopoulou, T. (2002a). "Integrating" Non-EU Migrants in the European Union: Ambivalent Legacies and Mutating Paradigms. Columbia Journal of European Law, 8(2), 181-201. Retrieved from http://cjel.law.columbia.edu/print/2002/integrating-non-eu-migrants-in-the-european-union-ambivalent-legacies-and-mutating-paradigms/

Kostakopoulou, T. (2002b). Long-Term Resident Third-Country Nationals in the European Union: Normative Expectations and Institutional Openings. Journal of Ethnic and Migration Studies, 28(3), 443-462.

https://doi.org/10.1080/13691830220146545

Lanzieri, G. (2010). Fewer, Older and Multicultural? A Projection of the Populations of the European Union Member States by Foreign/National Background. Eurostat Statistical Working Paper. Retrieved from https://ec.europa.eu/eurostat/web/products-statistical-working-papers/-/KS-RA-11-019

Lindberg, L. (1963). The Political Dynamics of European Economic Integration. Stanford: Princeton University Press.

Malmström, C. (2014). “Commissioner Malmström Welcomes the Parliament's Vote on the New EU Home Affairs' Funds 2014-2020. European Commission Press Release, 13 March. Retrieved from http://europa.eu/rapid/press-release_MEMO-14-188_en.htm.

Mathieson, J., Popay, J., Enoch, E., Escorel, S., Hernandez, M., Johnston, H. \& Rispel, L. (2008). Social Exclusion. Meaning, Measurement and Experience and Links to Health Inequalities. A Review of Literature, WHO Social Exclusion Knowledge Network, Background Paper 1.

Mulcahy, S. (2011). Europe's Migrant Policies: Illusions of Integration. Basingstoke: Palgrave Macmillan.

Murphy, C. (2009). Immigration, Integration and Citizenship in European Union Law: The Position of Third Country Nationals. Hibernian Law Journal, 8, 155-177.

Niemann, A. (2006). Explaining Decisions in the European Union. Cambridge: Cambridge University Press.

Niemann, A. \& Schmitter, P.C. (2009). Neofunctionalism. In A. Wiener \& T. Diez, (Eds.). European Integration Theory, 2nd ed. (pp. 45-66). Oxford: Oxford University Press.

OECD. (2016). Recruiting Immigrant Workers: Europe. Paris: OECD Publishing.

Oosterom-Staples, H. (2007). The Family Reunification Directive: A Tool Preserving Member State Interest or Conducive to Family Unity? In A. Baldaccini, H. Toner, \& P. E. Guild (Eds.). Whose Freedom, Security and Justice? EU Immigration and Asylum Law and Policy (pp. 451-488). Oxford: Hart Publishing.

Ortensi, L., Pasini, N.; Regalia, M. \& Van Wolleghem P.G. (2018). Immigration and the Future of Europe. In Fondazione ISMU, Twenty-third report on Migration in Italy (pp. 65-79). Milan:

MacGraw-Hill Education. Retrieved from

http://www.ismu.org/twenty-third-italian-report-on-migration/ 
Pratt, S. (2015). EU Policymaking and Research: Case Studies of the Communication on a Community Immigration Policy and the Common Basic Principles for Integration. In P. Scholten, H. Entzinger, R. Penninx, \& S. Verbeek (Eds.). Integrating Immigrants in Europe: Research-Policy Dialogues (pp. 117-131). Amsterdam: IMISCOE Research Series.

Ramboll (2011). Synthesis of the National Evaluation Reports on Implementation of Actions Co Financed by the European Fund for the Integration of Third-Country Nationals from 2007 to 2009 and Report at European Union Level Final Report. Brussels: Ramboll.

Ramboll (2013). Synthesis of the National Evaluation Reports .on the results and impacts of actions cofinanced by the European Fund for the Integration of third-country nationals from 2007 to 2010. Brussels: Ramboll.

Ramboll (2018a). Interim Evaluation of the Asylum, Migration and Integration Fund, Final Report. Luxembourg: Publications Office of the European Union.

Ramboll (2018b). Ex post evaluation of the European Fund for the Integration of Third-Country Nationals for 2011-2013 and Community Actions for 2007-2010. Luxembourg: Publications Office of the European Union.

Radaelli, C. (2003). The Europeanization of Public Policy. In K. Featherstone, \& C. M. Radaelli (Eds.). The Politics of Europeanization (pp. 27-56). New York: Oxford University Press.

Scholten, P. \& Penninx, R. (2016). The Multilevel Governance of Migration and Integration'. In B. Garcés-Mascareñas \& R. Penninx (Eds.), Integration Processes and Policies in Europe. Contexts, Levels and Actors (pp. 91-108). Amsterdam: IMISCOE Research Series.

Schnapper, D. (1994). The Debate on Immigration and the Crisis of National Identity. West European Politics, 17(2), 127-139.

https://doi.org/10.1080/01402389408425018

Schmitter, P.C. (1970). A Revised Theory of Regional Integration. International Organization, 24(4), 836-868.

https://doi.org/10.1017/S0020818300017549

Schmitter, P.C. (2004). Neo-Neofunctionalism. In A. Wiener \& T. Diez (Eds), European Integration Theory,1st edn (pp. 46-74). Oxford: Oxford University Press.

Szyszczak, E. (2006). Experimental Governance: The Open Method of Coordination. European Law Journal, 12(4), 486-502.

https://doi.org/10.1111/j.1468-0386.2006.00329.x

Urth, H. (2005). Building a Momentum for the Integration of Third-Country Nationals in the European Union. European Journal of Migration and Law, 7(2), 163-180. https://doi. org/10.1163/1571816054762179

Van Wolleghem P.G. (2017). Why Implement without a Tangible Threat? The Effect of a Soft Instrument on National Migrant Integration Policies. JCMS: Journal of Common Market Studies, 55(5), 1127-1143. https://doi.org/10.1111/jcms.12553

Van Wolleghem P.G. (2019a). The EU's Policy on the Integration of Migrants. A case of Soft-Europeanization? Basingstoke: Palgrave Macmillan.

Van Wolleghem P.G. (2019b). The crisis of the European Asylum system and the new Italian government. In Fondazione ISMU, The twenty-fourth Italian Report on Migrations 2018. Milan: Fondazione ISMU. Retrieved from

http://www.ismu.org/en/the-twenty-fourth-italian-report-on-migrations-2018 
Vanhercke, B. (2012). Social Policy at EU Level: From the Anti-poverty Programmes to Europe 2020. European Social Observatory, Vol. VC/2012/0658. Retrieved from http://www.ose.be/

Velluti, S. (2007). What European Union Strategy for Integrating Migrants? The Role of OMC Soft Mechanisms in the Development of an EU Immigration Policy. European Journal of Migration and Law, 9(1), 53-82.

https://doi.org/10.1163/138836407x179300

Westerby, R. (2018). Follow the Money. Assessing the use of EU Asylum, Migration and Integration Fund (AMIF) funding at national level. UNHCR and ECRE. Retrieved from https://www.ecre.org/follow-the-money-a-critical-analysis-of-the-implementation-of-the-eu-asylum-migration-integration-fund-amif/.

Wischenbart, R. (1994). National Identity and Immigration in Austria. Historical Framework and Political Dispute. West European Politics, 17(2), 72-90.

https://doi.org/10.1080/01402389408425015

Zaun, N. (2017). States as Gatekeepers in EU Asylum politics: Explaining the Non-adoption of a Refugee Quota System. JCMS: Journal of Common Market Studies, 38(5), 751-777. https://doi.org/10.1111/jcms.12663 